\title{
Human Immunodeficiency Virus-1 Glycoproteins gp120 and gp160 Specifically Inhibit the CD3/T Cell-Antigen Receptor Phosphoinositide Transduction Pathway
}

\author{
Daniel Cefai, “ Patrice Debre, * Michel Kaczorek, ${ }^{\ddagger}$ Thierry Idziorek, ${ }^{5}$ Brigitte Autran, ${ }^{\star}$ and Georges Bismuth* \\ ${ }^{*}$ Laboratoire d'Immunologie Cellulaire et Tissulaire, Centre d'Examen et de Recherche en Virologie et Immunologie (CERVI), \\ Group Hospitalier (GH) Pitié-Salpétrière, Paris, France; ${ }^{\ddagger}$ Pasteur Vaccins, BP 101, 27100 Val de Reuil, France; and ${ }^{\S}$ Laboratoire \\ de Biologie et Génétique des Infections Rétrovirales, CERVI, GH Pitié-Salpétrière, Paris, France
}

\begin{abstract}
The interference of the recombinant HIV-1 glycoproteins gp160 and gp120 with the CD3/T cell antigen receptor (TcR)mediated activation process has been investigated in the CD4+ diphtheria toxoid-specific human P28D T cell clone. Both glycoproteins clearly inhibit the $\mathbf{T}$ cell proliferation induced in an antigen-presenting cell (APC)-free system by various cross-linked monoclonal antibodies specific for the $\mathrm{CD} 3$ molecule or the TcR $\alpha$ chain (up to $80 \%$ inhibition). Biochemical studies further demonstrate that exposure of the $T$ cell clone to both glycoproteins (gps) specifically inhibits the CD3/TcR phospholipase C (PLC) transduction pathway, without affecting the CD3/TcR cell surface expression. Thus, inositol phosphate production, phosphatidic acid turnover, intracellular free calcium, and intracellular pH increase induced by CD3/TcRspecific MAbs are specifically impaired in gps-treated P28D T cells. Addition of purified soluble CD4 prevents binding of gps to $T$ cells and overcomes all observed inhibitions. Maximal inhibitions are obtained for long-term exposure of the $T$ cell clone to gps (16 h). No early effect of gps is observed. By contrast, gp160 and gp120 fail to suppress the CD2-triggered functional and biochemical P28D $T$ cell responses. These results demonstrate that, in addition to their postulated role in the alteration of the interaction between CD4 on T lymphocytes and MHC class II molecules on APC, soluble HIV-1 envelope glycoproteins may directly and specifically impair the CD3/TcR-mediated activation of PLC in uninfected T cells via the CD4 molecule. (J. Clin. Invest. 1990. 86:2117-2124.) Key words: acquired immunodeficiency syndrome • immunosuppression $\bullet T$ cell activation $\bullet$ phospholipase $C \cdot C D 4$
\end{abstract}

\section{Introduction}

HIV-1 infection in humans results in quantitative and qualitative defects in the CD4 helper/inducer T cell function (1). The selective infection of CD4+ T cells by HIV-1 is governed through the high affinity interaction between the viral envelope glycoprotein gp120 and T cell surface expressed determinants of the CD4 molecule. Different works showed that soluble gp120 itself could exert a suppressive effect on $T$ cell responses. Thus, gp120 could alter the antigen-specific proliferation of human uninfected CD4 $+\mathrm{T}$ cells $(2-4)$ thereby

Address reprint requests to Dr. Daniel Cefai, Laboratoire d'Immunologie Cellulaire et Tissulaire, CNRS UA186, Bat. CERVI, 83 Bvd. de l'Hôpital, 75013 Paris, France.

Received for publication 16 November 1989 and in revised form 27 July 1990.

J. Clin. Invest.

(C) The American Society for Clinical Investigation, Inc.

$0021-9738 / 90 / 12 / 2117 / 08 \$ 2.00$

Volume 86, December 1990, 2117-2124 probably contributing to a part of the HIV-1 observed immunosuppressive effects. Such proliferative responses require that soluble antigen should be processed by antigen-presenting cells (APC) ${ }^{1}$ and presented to T cells in the context of MHC class II molecules (5). They also usually require that CD4 on T cells bind to monomorphic epitopes of MHC class II molecules on APC (6). It was therefore proposed that gp120 could competitively block this interaction by binding to CD4. This was further supported by the finding that inhibition of $\mathrm{T}$ cell function by gp 120 does not require the cytoplasmic domain of CD4 (4). Purified CD4+ T cells infected in vitro with HIV-1 have been shown to exhibit a selective signaling defect in their proliferative and biochemical responses to CD3-specific MAbs (7). Gp1 20 was also shown to inhibit $T$ cell activation triggered by various mitogens (8) or CD3-specific MAbs in the presence of APC (9). However, participation of the gp120 competitive blocking effect in this inhibition remains unclear.

Recent works have shown it to be likely that the CD4 molecule may have a signaling role in human $T$ cells and is perhaps directly involved in signal transduction. The main evidence was that CD4-specific MAbs could inhibit $\mathrm{T}$ cell stimulation driven by ligands such as' mitogenic lectins or CD3-specific MAbs (10-12). Bank et al. showed that CD4 could deliver inhibitory signals to $\mathrm{T}$ cells independent of $\mathrm{MHC}$ class II recognition (13). It was therefore suggested that binding of gp120 to CD4 may also transmit negative signals to T cells (9).

In this report, a human diphtheria toxoid (DT)-specific CD4+ T cell clone was used to investigate how purified HIV-1 glycoproteins gp160s and gp120s could alter the CD3/T cell antigen receptor ( $\mathrm{TcR}$ )-transducing biochemical pathway mediated independent of accessory cells by MAbs specific both for the TcR $\alpha / \beta$ heterodimer or the CD3 molecule.

\section{Methods}

Reagents. Myo-[2- $\left.{ }^{3} \mathrm{H}\right]$ inositol $(10-20 \mathrm{Ci} / \mathrm{mmol})$ and $\left[{ }^{32} \mathrm{P}\right]$ orthophosphoric acid (carrier free) were from Amersham International, Amersham, UK. $\left[6-{ }^{3} \mathrm{H}\right]$ thymidine $(1 \mathrm{Ci} / \mathrm{mmol})$ was from ORIS, Gif sur Yvette, France. Diphtheria toxoid $(5,000 \mathrm{Lf} / \mathrm{ml})$ was kindly provided by Dr. Perquin, Institut Pasteur, Paris, France.

Purification of gp160s, gp120s, and soluble CD4 (sT4). gp160s (s for soluble) is a derivative of the HIV-1 LAV/BRU strain envelope glycoprotein (14) that was deleted of its transmembrane domain and its cleavage site (15). Expression was obtained by infection of BHK21 cells with the vaccinia recombinant virus clone 1163 (15). Secreted

1. Abbreviations used in this paper: APC, antigen presenting cell; BCECF/AM, 2',7'-bis-(2-carboxyethyl)-5-carboxyfluorescein, tetraacetoxymethylester; $\left[\mathrm{Ca}^{2+}\right]_{i}$, intracellular free calcium; DAG, diacylglycerol; DT, diphtheria toxoid; gp, glycoprotein; gps, soluble gp; IP, inositol phosphate; PA, phosphatidic acid; PI, phosphatidyl inositol; PKC, protein kinase C; PLC, phospholipase C; TcR, T cell-antigen receptor. 
gp160s was purified by gel filtration and reverse HPLC (Kaczorek, M. unpublished results). Gp120s is a derivative of the HIV-1 envelope glycoprotein (6) that was deleted of its gp41 moieties (15). Expression was obtained as described above by infection of BHK21 cells with the vaccinia recombinant virus clone 1132 . Secreted $g p 120$ s was purified by gel filtration and affinity lectin chromatography (not published). Purity of both supernatants was greater than 75 and $90 \%$, respectively, as estimated by HPLC and SDS-PAGE (not shown). A control supernatant was purified in the same conditions from BHK21 cells infected with wild-type vaccinia virus. A soluble form of the extracellular moiety of the CD4 protein was produced in $\mathrm{CHO}$ cells using previously described procedures (16). After ammonium sulfate precipitation, resuspended soluble CD4 (sT4) was extensively dialyzed and purified by FPLC on a mono-Q Sepharose column (Pharmacia, Inc., Uppsala, Sweden). Purity of sT 4 was $>90 \%$ as assessed by SDS-PAGE and FPLC profiles (not shown).

Monoclonal antibodies. CD3-specific MAb X35 (IgG2a), a kind gift of Dr. Bourel, Centre National de Transfusion Sanguine, Rennes, France, and CD2-specific MAbs X11 and D66, kindly provided by Dr. A. Bernard, Institut Gustave Roussy, Villejuif, France, were previously described $(17,18)$. MAbs CD3-4B5 (IgG1) and SMC2 (IgM), both specific for the $\mathrm{CD} 3$ molecule, were obtained through the exchanges of the 4th International Workshop and Conference on Human Leukocyte Differentiation Antigens. UCHT1 myeloma cells were kindly given by Dr. P. C. L. Beverley, Imperial Cancer Research Center, London, UK. MAb 1C5V $\alpha$ (IgG1) specific for the $\alpha$ chain of the P28D TcR was developed in our laboratory (18a). Purified MAbs OKT4 and OKT4a (IgG2a) were from Ortho Pharmaceutical, Raritan, NJ. Gp 110-specific MAb 110.4 was obtained from Genetic Systems Corp., Seattle, WA. All MAbs, except OKT4 and OKT4a, were used as ascitic fluid.

$T$ cells. Human DT-specific T cell clone P28D was derived from an HLA-DR6/7 healthy individual as previously described (19). It was propagated in complete culture medium consisting of RPMI 1640 supplemented with $5 \%$ pooled human serum, $2 \mathrm{mM}$ L-glutamine, 1 $\mathrm{mM}$ Na-pyruvate, penicillin, and streptomycin by periodic restimulation with the antigen presented by an autologous EBV-transformed $B$ cell line (B LCL). Recombinant IL-2 (10-20 U/ml) was added every 3 $\mathrm{d}$ to maintain cell growth and viability. In all experiments the cells were used at day 14 of the restimulation cycle, $3 \mathrm{~d}$ after the last addition of fresh IL-2 (> 95\% in the G0/G1 phase of the cell cycle, not shown).

$T$ cell proliferation assays were performed in 96-well flat-bottomed microtiter plates in complete culture medium in a final volume of 200 $\mu \mathrm{l} .5 \times 10^{4} \mathrm{~T}$ cells per well were stimulated with the specified MAbs in the presence or absence of gps $(4 \mu \mathrm{g} / \mathrm{ml})$. All CD3/TcR-specific MAbs were cross-linked with a 1/400 dilution of a rabbit anti-mouse Ig antiserum. Antigen-specific proliferation assays were carried out in the same conditions with DT $(30 \mu \mathrm{g} / \mathrm{ml})$ using $2.5 \times 10^{4} \mathrm{MHC}$ class II-expressing $\mathrm{L}$ cells (see below) per well as APC. Proliferation was measured after a $3-\mathrm{d}$ culture by a 16 -h pulse with $1 \mu \mathrm{Ci}$ per well of $\left[{ }^{3} \mathrm{H}\right]$ thymidine.

For immunofluorescence analysis, an indirect staining with fluorescein isothiocyanate-conjugated affinity-purified goat anti-mouse IgG Fc fragments (Nordic Immunology, Tilburg, The Netherlands) was used as described (10). Immunofluorescence analyses were performed on a Facstar cell sorter (Becton Dickinson \& Co., Mountain View, CA).

MHC class II transfectants. Mouse $\mathrm{L}$ cell fibroblast transfectant L12.2 (DR $\alpha:$ DR7 $\beta 1$ ) was produced as reported (20). It was shown to efficiently present DT antigen to P28D T cell clone in the context of the DR7 $\beta 1$ molecule of the DR7 haplotype (21). Cells were cultured in RPMI 1640 medium supplemented with $10 \%$ FCS, 2 mM L-glutamine, $50 \mathrm{U} / \mathrm{ml}$ penicillin, $50 \mu \mathrm{g} / \mathrm{ml}$ streptomycin, and $250 \mu \mathrm{g} / \mathrm{ml}$ Geneticin (G418) (Sigma Chemical Co., St. Louis, MO).

Phospholipase C activity. Measurement of inositol phosphates (IPs) production and ${ }^{32} \mathrm{P}$-labeling of phosphatidic acid (PA) were performed as previously described $(22,23)$. Briefly, for the IPs production assay, $T$ cells were overnight-labeled with myo- $\left[2-{ }^{3} \mathrm{H}\right]$ inositol $(10 \mu \mathrm{Ci} / \mathrm{ml})$ in inositol-free medium, washed, and incubated $\left(10^{7} / \mathrm{ml}\right)$ in Hanks' solution containing $10 \mathrm{mM} \mathrm{LiCl}$ for $20 \mathrm{~min}$ at $37^{\circ} \mathrm{C}$. Aliquots of the cell suspension $(100 \mu \mathrm{l})$ were then stimulated with the different MAbs or with antigen-pulsed DR7 $\beta 1$ transfectants ( $50 \mu \mathrm{g} / \mathrm{ml}$ of DT overnight) for $30 \mathrm{~min}$ at $37^{\circ} \mathrm{C}$. IPs were quantified by anion-exchange chromatography on Dowex AG 1-X8 in the formate form (Bio-Rad Laboratories, Richmond, CA), as reported (13). For PA analysis, T cells were washed twice in a phosphate-free buffer containing $20 \mathrm{mM}$ Hepes (pH 7.2), $150 \mathrm{mM} \mathrm{NaCl}, 1 \mathrm{mM} \mathrm{MgCl}, 5 \mathrm{mM} \mathrm{KCl}, 1 \mathrm{mM} \mathrm{CaCl}$, and $0.1 \%$ glucose. Cells were resuspended in the same buffer $\left(10^{7} / \mathrm{ml}\right)$ and incubated in carrier-free $\left[{ }^{32} \mathrm{P}\right]$ orthophosphoric acid $(50 \mu \mathrm{Ci} / \mathrm{ml})$ for $60 \mathrm{~min}$ at $37^{\circ} \mathrm{C}$. Aliquots of the cell suspension $(100 \mu \mathrm{l})$ were then stimulated with the different MAbs for $30 \mathrm{~min}$ at $37^{\circ} \mathrm{C}$. The reaction was stopped with concentrated $\mathrm{HCl}$, the ${ }^{32} \mathrm{P}$-labeled phospholipids extracted, separated, and PA quantified (22).

Determination of intracellular free $\mathrm{Ca}^{2+}$ concentration. P28D T cells were washed in a solution containing $25 \mathrm{mM}$ Hepes, $\mathrm{pH} 7.2,125$ $\mathrm{mM} \mathrm{NaCl}, 5 \mathrm{mM} \mathrm{KCl}, 1 \mathrm{mM} \mathrm{NaH} \mathrm{PO}_{4}, 1 \mathrm{mM} \mathrm{CaCl}_{2}, 0.5 \mathrm{mM}$ $\mathrm{MgCl}_{2}$, and $0.5 \%$ glucose, resuspended $\left(10^{7} / \mathrm{ml}\right)$ in the same medium, and incubated in the dark for $30 \mathrm{~min}$ at $37^{\circ} \mathrm{C}$ with membrane-permeable Fura-2 acetoxymethyl ester, $3 \mu \mathrm{M}$ (Calbiochem-Behring Corp., San Diego, CA). Cells were then washed and transferred to quartz cuvettes thermostatically controlled at $37^{\circ} \mathrm{C}$. Fura-2 fluorescence was recorded on an LS-5B luminescence spectrometer (Perkin-Elmer Corp., Nancy, France) using 10-nm slit widths for both excitation and emission as described (14). [ $\left.\mathrm{Ca}^{2+}\right]_{i}$ (intracellular free calcium) was calculated according to the equation $\left[\mathrm{Ca}^{2+}\right]_{\mathrm{i}}=225 \times(R-R \min ) /(R \max$ $-R) \times \mathrm{Sf} 380 / \mathrm{Sb} 380$ as published by Grynkiewicz et al. (24).

Intracellular pH measurements. T cells were suspended $\left(10^{7} / \mathrm{ml}\right)$ in PBS, pH 7.2, and incubated with $2.5 \mu \mathrm{g} / \mathrm{ml}$ of the esterified indicator 2',7'-bis-(2-carboxyethyl)-5-carboxyfluorescein, tetraacetoxymethylester (BCECF/AM) (Calbiochem) at $37^{\circ} \mathrm{C}$ for $30 \mathrm{~min}$. Loaded cells were then allowed to equilibrate for $30 \mathrm{~min}$ in the same medium, washed once, resuspended in $2.5 \mathrm{ml}$ of the same medium, and transferred into a $37^{\circ} \mathrm{C}$ prewarmed quartz glass cuvette. Agonist was added at the indicated times after establishment of a stable base line. BCECF fluorescence was measured with an LS-5B luminescence spectrometer (Perkin-Elmer) using wavelengths for excitation and emission of 500 and $530 \mathrm{~nm}$, respectively. Calibration of fluorescence signals with intracellular $\mathrm{pH}\left(\mathrm{pH}_{\mathrm{i}}\right)$ was carried out using nigericin and $\mathrm{K}^{+}$medium as described (25).

\section{Results}

gp160s and gp120s inhibit P28D T cell proliferation triggered via the $C D 3 / T c R$ molecular complex. Mitogenic responses of $T$ lymphocytes, including resting P28D T cells (not shown) to soluble CD3/TcR-specific MAbs usually depend upon the presence of accessory cells. Since gp120 has been shown to interfere with the APC-T cell interaction $(2,4)$, the CD3/TcRmediated proliferative signal was delivered independent of autologous peripheral blood mononuclear cells by cross-linked antibodies. As shown in Fig. 1 (B), gp160s and gp120s inhibit P28D proliferation induced by CD3-specific MAb X35 in a dose-dependent manner ( 45 to $80 \%$ maximal inhibition depending on the experiments, $n=5$ ). Note that HIV-1 glycoproteins used alone did not induce any significant $P 28 D$ proliferation. In agreement with previous works $(2,4,9)$, the antigen-specific proliferation, performed in parallel with an optimal concentration of DT $(30 \mu \mathrm{g} / \mathrm{ml})$ presented by DR7 $\beta 1$ transfected fibroblasts, was also found to be severely impaired by gps $(A)$. Note that in this system of antigen presentation using transfected mouse fibroblasts as APC, only CD4-MHC class II molecules interaction may occur. No other cell adhesion molecules that primarily facilitate physical interaction between APC and T cell (i.e., leukocyte function associated 


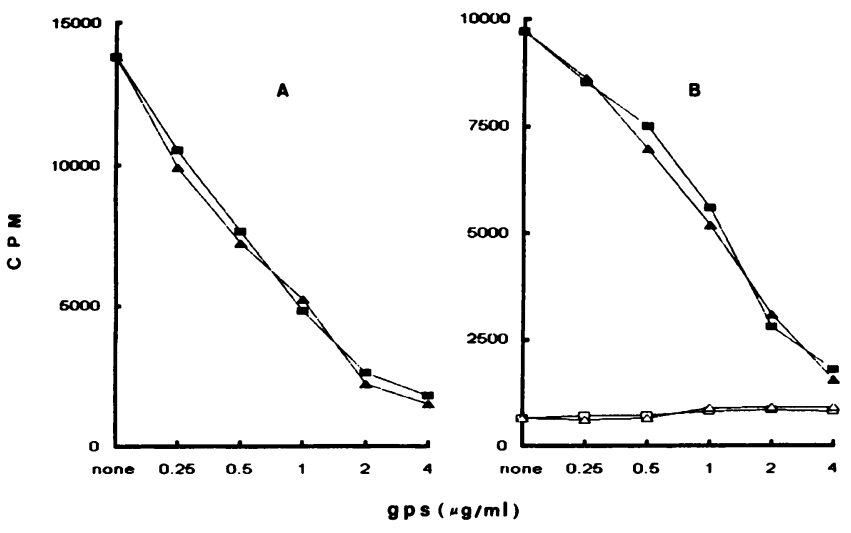

Figure 1. Dose-dependent inhibitory effect of gp160s and gp120s on antigen-specific and CD3-induced P28D T cell proliferation. $(A) \mathrm{T}$ cells were stimulated with DT $(30 \mu \mathrm{g} / \mathrm{ml})$ presented by DR $\alpha$ :DR7 $\beta 1$ transfected fibroblasts $\left(2.5 \times 10^{4}\right.$ per well) in the presence of various concentrations of gp160s ( $(\omega)$ or gp120s ( $\triangle$ ). Proliferation was measured on day 3 after a $16-\mathrm{h}$ pulse with $\left[{ }^{3} \mathrm{H}\right]$ thymidine. $(B) \mathrm{T}$ cells were stimulated with anti-CD3 MAb X35 (1/400 dilution of ascitic fluid) in the presence of various concentrations of gp160s (a) or $\mathrm{gp120s}(\Delta)$. The effect of $\mathrm{gp} 160 \mathrm{~s}(\square)$ and $\mathrm{gp} 120 \mathrm{~s}(\Delta)$ used alone is also shown. Proliferation was measured as in $A$. Results are expressed as the mean cpm of triplicate determinations (SD $<10 \%$ ). Representative of five different experiments.

antigen/intercellular adhesion molecule family), are involved (Cefai, D., unpublished results).

The effects of gps on the P28D proliferation induced by different CD3/TcR or CD2-specific MAbs were compared to search for a specific effect of gps on the CD3/TcR-stimulated proliferation. Table I shows that stimulation by various CD3specific MAbs with different isotypes, as well as by MAb $1 \mathrm{C5V} \alpha$ specific for the $\alpha$ chain of P28D TcR, is clearly impaired, indicating that gps inhibit all the triggering signals mediated through the CD3/TcR molecular complex. As shown,

Table I. Specific Inhibition by gp120s and gp160s of the P28D Proliferation Induced via CD3 but Not via CD2*

\begin{tabular}{|c|c|c|c|c|c|}
\hline \multirow[b]{2}{*}{ MAbs } & \multicolumn{5}{|c|}{$\left[{ }^{3} \mathrm{H}\right]$ Thymidine incorporation } \\
\hline & Control & $\mathrm{gp} 120 \mathrm{~s}$ & $\begin{array}{c}\mathrm{gp} 120 \mathrm{~s} \\
+\mathrm{sT} 4\end{array}$ & gp160s & $\begin{array}{c}\text { gp160s } \\
+ \text { sT4 }\end{array}$ \\
\hline & \multicolumn{5}{|c|}{ cpm } \\
\hline None & 120 & 160 & 140 & 150 & 180 \\
\hline X35 (CD3) & 10,114 & 2,670 & 9,403 & 2,326 & 9,100 \\
\hline UCHT1 (CD3) & 11,542 & 2,080 & 10,818 & 2,254 & 10,724 \\
\hline CD3-4B5 (CD3) & 9,687 & 5,030 & 8,854 & 5,135 & 9,012 \\
\hline SMC2 (CD3) & 8,664 & 4,887 & 8,245 & 4,936 & 8,126 \\
\hline $1 \mathrm{C} 5 \mathrm{~V} \alpha(\mathrm{TcR})$ & 7,274 & 3,192 & 6,846 & 3,055 & 7,026 \\
\hline X11/D66 (CD2) & 50,192 & 48,192 & ND & 47,668 & 49,118 \\
\hline
\end{tabular}

$* 5 \times 10^{4}$ P28D T cells per well were cultured with the various MAbs (1/400 final dilution) in the presence or absence of gp 160s or gp120s $(4 \mu \mathrm{g} / \mathrm{ml})$ and with or without addition of $4 \mu \mathrm{g} / \mathrm{ml}$ of soluble CD4 (sT4). Anti-CD3 and anti-TcR MAbs were cross-linked with a 1/400 dilution of a rabbit anti-mouse Ig antiserum. Proliferation was measured on day 3 after a $16-\mathrm{h}$ pulse with $1 \mu \mathrm{Ci}$ of $\left[{ }^{3} \mathrm{H}\right]$ thymidine. $\mathrm{Re}-$ sults are expressed as the mean cpm of triplicate determinations (SD $<10 \%$ ). Representative of four different experiments. ND, not done. addition of soluble CD4 sT4 $(4 \mu \mathrm{g} / \mathrm{ml})$ was found to reverse in all cases the gps-induced inhibition. A control supernatant purified from wild-type vaccinia virus-infected BHK21 cells failed to inhibit the P28D proliferative responses to the different CD3-specific MAbs, even at protein concentrations fivefold higher than gps preparations (not shown). Moreover, cell viability, as assessed by trypan blue dye exclusion, was $>98 \%$ in control and gps-treated $\mathrm{T}$ cells. As suggested in previous studies on HIV-1-infected T cells $(7,26)$, the proliferation induced by a mitogenic combination of two CD2-specific MAbs X11 + D66 was unaffected by gps. These results demonstrate that only the CD3/TcR-stimulating pathway is inhibited by gps in P28D T cells. We therefore conclude that gp160s and gp120s specifically inhibit, in an APC-free system, the CD3/TcR pathway leading to $T$ cell proliferation. These results also suggest that the observed inhibitions probably involve a mechanism distinct from or additional to the alteration of the specific interaction between CD4 on T cells and MHC class II determinants on APC.

gp160s and gp120s inhibit the phosphoinositide transduction pathway mediated via the CD3/TcR but not the CD2. In the $T$ cell activation process, hydrolysis by phospholipase $C$ (PLC) of inositol phospholipids is one of the earliest biochemical events triggered by specific antigen (27) or MAbs directed against cell surface activation molecules like the CD3/TcR complex $(28)$ or the CD2 $(22,29)$. As a result of this enhanced activity of PLC, both an accelerated turnover of phosphoinositides $(23)$ and an increased production of IPs $(22,28)$ are usually noticed. The results presented above led us to search for a possible inhibitory effect of the HIV-1 glycoproteins on the PLC signaling pathway.

P28D T cells were labeled with $\left[{ }^{3} \mathrm{H}\right]$ inositol for $24 \mathrm{~h}$ and incubated with $4 \mu \mathrm{g} / \mathrm{ml}$ of gp $160 \mathrm{~s}$ or gp 120 s or wild-type vaccinia virus-infected BHK21 cells control supernatant for different periods of time. T cells were stimulated for $30 \mathrm{~min}$ with CD3-specific MAb X35 and IPs production was measured. As shown in Fig. 2, we did not find any significant alteration of the IPs production for short term exposure of P28D T cells to gps. However, a significant inhibition appeared after $6 \mathrm{~h}$ of incubation with gp160s and gp120s and was usually maximal after $16 \mathrm{~h}$. This time of incubation was chosen to further explore inhibitory effects of both gps on the P28D T cell activation process. Note that IPs formation was not affected at any time in P28D T cells incubated with the control supernatant from BHK21 cells infected with wild-type vaccinia virus.

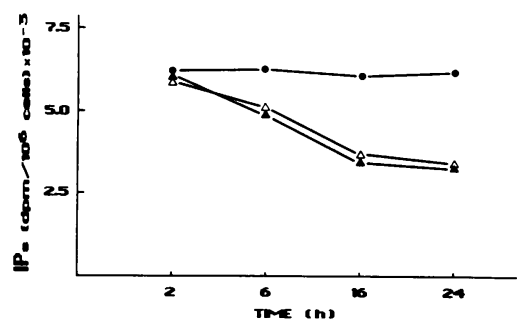

Figure 2. Time-dependent inhibition by gp160s of IPs production induced by CD3 stimulation. $T$ cells were labeled with myo$\left[2-{ }^{3} \mathrm{H}\right]$ inositol for $24 \mathrm{~h}$. During this labeling period, cells were treated for the indicated times with $4 \mu \mathrm{g} / \mathrm{ml}$ of $\mathrm{gp} 160 \mathrm{~s}(\Delta)$ or gp120s ( $\Delta$ ) or supernatant from wildtype vaccinia virus-infected BHK21 cells as a control (๑). At the end of the labeling period, cells were washed and stimulated for $30 \mathrm{~min}$ with CD3-specific MAb UCHT1 (1/400 final dilution). IPs production was quantified by anion exchange chromatography as described in Methods. 
As shown in Fig. 3 (top) only phosphoinositide hydrolysis triggered via the CD3/TcR molecular complex either by specific antigen (DT), presented by DR7 $\beta 1$-transfected fibroblasts, or by CD3-specific MAb UCHT1 was substantially decreased by a 16 -h pretreatment with $4 \mu \mathrm{g} / \mathrm{ml} \mathrm{gp} 160 \mathrm{~s}$ (reduction of IPs accumulation up to 60 and $45 \%$, respectively). Incubation with gp120s led to the same range of inhibitions (not shown). Addition of sT4 during incubation of cells with gps almost completely reversed the observed inhibitory effects. It is important that, in agreement with functional results, the inositol phospholipid hydrolysis triggered by $30 \mathrm{~min}$ of stimulation with the CD2-specific MAbs X11 + D66 was identical in control and gps-treated cells. Time-course study showed no inhibition at 5 and $15 \mathrm{~min}$ of stimulation by CD2 (not shown). Note that gps alone failed to induce any significant IPs formation.

To confirm these results, PA labeling was measured in ${ }^{32} \mathrm{P}$ preincubated P28D T cells, since its increased turnover has been reported as the direct consequence of diacylglycerol (DAG) neosynthesis and phosphorylation during the $T$ cell activation process (29). For this purpose, P28D T cells incubated $16 \mathrm{~h}$ with or without gp $160 \mathrm{~s}$ were labeled near to isotopic equilibrium with ${ }^{32} \mathrm{P}$ and then stimulated for $30 \mathrm{~min}$ with MAbs X35 or X11 + D66 (Fig. 3, bottom). According to the IPs measurements, gps were found to reduce PA turnover only in CD3 (up to 50\% inhibition) and not in CD2-stimulated T cells. Addition of sT4 could also prevent the gps-induced inhibition of the CD3 pathway. CD3-triggered IPs accumulation and PA turnover were not affected in P28D T cells incubated with the control supernatant from wild-type vaccinia virusinfected BHK21 cells (not shown). These results clearly show
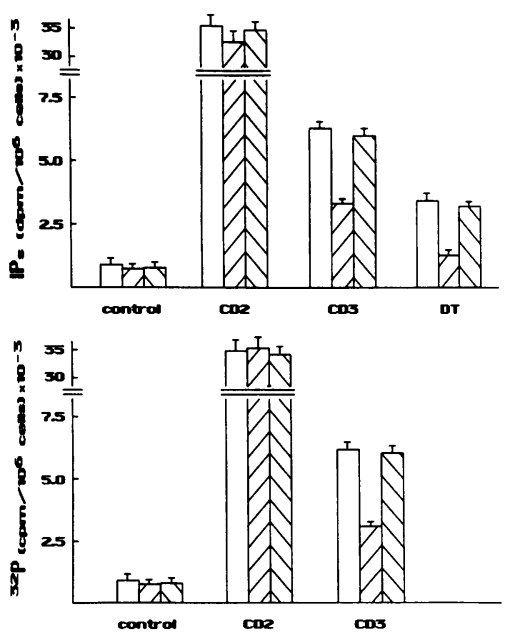

Figure 3. gp160s inhibits PLC activity triggered via the $\mathrm{CD} 3 / \mathrm{TcR}$ but not CD2 in P28D T cells. (Top) T cells were labeled to isotopic equilibrium with myo-[2${ }^{3} \mathrm{H}$ ]inositol in the absence ( $\square$ ) or the presence of $4 \mu \mathrm{g} / \mathrm{ml}$ of gp160s alone (可) or together with $4 \mu \mathrm{g} / \mathrm{ml}$ of sT4 ( $\$$ ). Labeled cells were stimulated for 30 min with the combination of X11 + D66 CD2-specific MAbs or the CD3-specific MAb X35 (1/400 dilution for each), or with $5 \times 10^{5}$

DR7 $\beta 1$ transfectants, prepulsed $18 \mathrm{~h}$ with $50 \mu \mathrm{g} / \mathrm{ml}$ of DT antigen. A $1 / 400$ dilution of a normal BALB/c ascitic fluid was used as a control. IPs were quantified as described in Methods. Each determination was performed in triplicate. Representative of three different experiments. (Bottom) T cells were incubated for $16 \mathrm{~h}$ with $4 \mu \mathrm{g} / \mathrm{ml}$ of

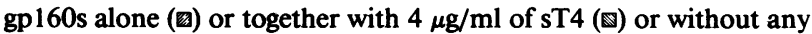
addition ( $\square$ ). Cells were then labeled to isotopic equilibrium with

${ }^{32} \mathrm{PO}_{4}$ and stimulated for $30 \mathrm{~min}$ at $37^{\circ} \mathrm{C}$ with the different MAbs or a normal BALB/c ascitic fluid. ${ }^{32} \mathrm{P}$-labeled phospholipids were then extracted and PA quantified as described in Methods. Results are expressed as the mean cpm for $10^{6}$ cells of triplicate determinations. Representative of three different experiments. that, in addition to their inhibitory effect on the CD3/TcR-induced proliferation, both HIV-1 glycoproteins may also specifically impair the CD3/TcR-induced production of phosphatidyl inositol (PI) cycle-related second messengers.

gp160s and gp120s binding to P28D T cells does not affect $C D 3 / T c R$ or $C D 2$ cell surface expression. We investigated whether the observed inhibition of the CD3-mediated signaling pathway by gps could be concomitant with a decrease in the cell surface CD3/TcR expression. P28D T cells were incubated with gp160s for $16 \mathrm{~h}$ and immunofluorescence studies were performed. As shown in Fig. 4, fluorescence analysis of gp160s-treated cells by gp110-specific MAb 110.4 clearly revealed the presence of bound gp160s at the P28D cell surface. Analysis with MAb OKT4a, which is known to compete with the binding of the viral glycoprotein on the CD4 surface molecule, revealed a markedly reduced level of OKT4a staining on gp160s-treated as compared with control cells. Gp160s-binding to CD4 was specific since addition of sT4 $(C)$ could prevent almost completely labeling by MAb 110.4 . Greater gp 160s concentrations failed to further block OKT4A staining or increase $110.4 \mathrm{MAb}$ fluorescence, suggesting that saturation of CD4 sites should be complete at $4 \mu \mathrm{g} / \mathrm{ml}$ (not shown). CD4 was stained with MAb OKT4, which is not affected by gp 120 binding (30). Reduction of CD4 membrane level (35 $\pm 4 \%, n$ $=4$ ) was seen in the gps-treated P28D cells. It is important that the expression of both the CD3/TcR complex and the CD2 molecule, as monitored with CD3-specific MAb X35 and CD2-specific MAb X11, remained unaltered (identical results with gp120s, not shown). These findings show that gp160s efficiently binds to P28D T-cell surface. They further rule out the hypothesis that the inhibitory effect of gp160s on the CD3/TcR pathway could be mediated by a decrease in the CD3/TcR membrane levels.

Stability of gp160s binding to CD4 was also measured. For that purpose P28D T cells were incubated with saturating concentrations of gp160s for $2 \mathrm{~h}$, washed out, and the expression of bound gp 160 and CD4 measured as a function of time. As shown in Table II, CD4 staining remained unaffected while a progressive loss of cell-surface gp 160 could be evidenced and was almost complete at $16 \mathrm{~h}$. At this time, proliferation studies were performed. P28D response to CD3-specific MAbs was unaltered (data not shown).

gp120s and gp160s inhibit the P28D CD3-mediated $\mathrm{Ca}^{2+}$ response. $\mathrm{CD} 3$ and $\mathrm{CD} 2$-specific MAbs induce a rapid and sustained rise in $\left[\mathrm{Ca}^{2+}\right]_{i}$ concentration in human $\mathrm{T}$ lymphocytes. This is likely to result from activation of the PLC pathway via the $C D 3 / T c R$ molecule $(28,29)$. As gps inhibited the CD3-triggered IPs production and PA turnover, we further performed $\mathrm{Ca}^{2+}$ measurements on P28D T cells preincubated with gp160s (Fig. 4). Overnight incubation of P28D T cells with gp160s could impair by $35 \pm 4 \%(n=4)$ the increase in $\left[\mathrm{Ca}^{2+}\right]_{\mathrm{i}}$ induced by the CD3-specific MAb UCHT1 (top left) (among our CD3-specific MAbs, UCHT1 induces the highest P28D Ca ${ }^{2+}$ responses, not shown). Confirming the biochemical data, the $\mathrm{Ca}^{2+}$ response to $\mathrm{CD} 2$ stimulation was unaffected (top right).

$\left[\mathrm{Ca}^{2+}\right]_{\mathrm{i}}$ increase in CD3 or CD2-stimulated P28D T cells involves both $\mathrm{Ca}^{2+}$ mobilization from intracellular stores linked to second messengers of the PLC pathway, mainly $(1,4$, 5) $\mathrm{IP}_{3}(28)$, and $\mathrm{Ca}^{2+}$ influx through cell surface voltage-independent $\mathrm{Ca}^{2+}$ channels (31). $\mathrm{Ca}^{2+}$ measurements were further performed in a medium supplemented with $3 \mathrm{mM}$ EGTA. 


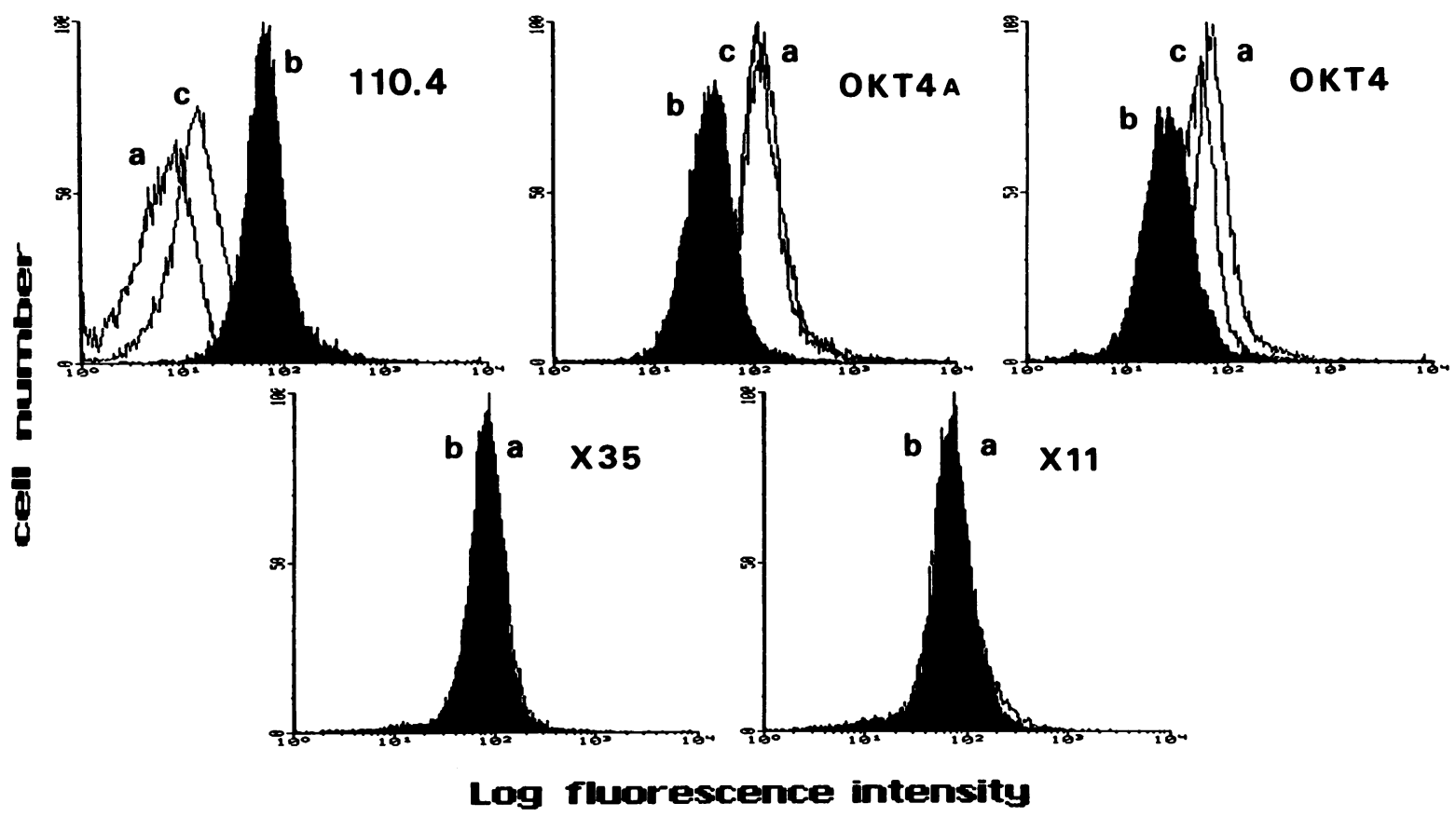

Figure 4. Immunofluorescence analysis of gp160s binding effect on CD2 and CD3 cell surface expression. P28D T cells were incubated overnight in complete culture medium in the absence $(a)$ or the presence $(b)$ of gp 160s $(4 \mu \mathrm{g} / \mathrm{ml})$. Specificity of gp $160 \mathrm{~s}$ binding was assessed by addition of sT4 together with gp160s $(c)$. Binding of gp160s on P28D cell surface was monitored with gp1 10-specific MAb 110.4 and competitive staining of OKT4A MAb. Expression of CD2, CD3, and CD4 molecules was analyzed with MAbs X11, X35, and OKT4, respectively.

Under these conditions, the observed $\mathrm{Ca}^{2+}$ response mainly reflects mobilization. As shown in Fig. 5 (bottom), CD3-induced mobilization of $\mathrm{Ca}^{2+}$ is inhibited in gps overnightpulsed P28D T cells $(48 \pm 4 \% ; n=3)$ as compared with control cells. No inhibition was seen in T cells incubated with gp160s together with sT4 (not shown). Further addition of exogenous $\mathrm{Ca}^{2+}$ induced quite similar $\mathrm{Ca}^{2+}$ influx in control and treated $\mathrm{T}$ cells. That may explain the smaller inhibition of $\mathrm{Ca}^{2+}$ response seen when experiment was performed in $\mathrm{Ca}^{2+}$-containing medium. Same results were obtained with gp120s (not shown). These findings show that both gps may specifically affect $\mathrm{Ca}^{2+}$ mobilization from intracellular stores after CD3 stimulation.

Table II. Time-dependent Loss of Cell-surface Bound gp160s in P28D T Cell Clone*

\begin{tabular}{ccccc}
\hline & \multicolumn{5}{c}{ Mean fluorescence } \\
\cline { 2 - 5 } MAbs & $0 \mathrm{~h}$ & $2 \mathrm{~h}$ & $6 \mathrm{~h}$ & $18 \mathrm{~h}$ \\
\hline OKT4 (CD4) & 52.98 & 50.36 & 46.42 & 48.76 \\
110.4 (gp120) & 92.86 & 80.82 & 51.48 & 11.44 \\
\hline
\end{tabular}

* P28D T cells were incubated in complete culture medium for $2 \mathrm{~h}$ at $37^{\circ} \mathrm{C}$ with $4 \mu \mathrm{g} / \mathrm{ml}$ of gp 160 s and either stained immediately with the indicated MAbs $(0 \mathrm{~h})$ or resuspended in fresh medium free of gp160s and reincubated at $37^{\circ} \mathrm{C}$. Staining of bound gp160s and CD4 was performed 2,6 , and $16 \mathrm{~h}$ later. In this representative experiment, background fluorescence control value (with goat anti-mouse FITC conjugate only) was 9.11 . Fluorescence of the cells measured with OKT4 MAb before incubation with gp160s was 48.14. Representative of three different experiments.
pHi response to $C D 3$ is decreased by gp160s and gp120s. CD3 and CD2-specific MAbs induce a sustained increase of $\mathrm{pH}_{\mathrm{i}}$ in P28D T cells within a few minutes. This alkalinization is mainly due to activation of the $\mathrm{Na}^{+} / \mathrm{H}^{+}$membrane exchanger by protein kinase $C$ (PKC) (32). We investigated whether gps could modify the $\mathrm{pH}_{\mathrm{i}}$ response induced by $\mathrm{CD} 3$ and CD2-specific MAbs. As shown in Fig. 6 (bottom) CD3specific MAb UCHT1-induced alkalinization was clearly decreased in the gps overnight-treated P28D T cells as compared with control cells. This inhibition could be reversed by addition of sT4 (not shown). By contrast, the CD2-induced alkalinization was unaffected (top).

\section{Discussion}

We demonstrated in this report that both HIV-1 glycoproteins gp120s and gp160s specifically inhibited the proliferative response triggered by various MAbs specific for the TcR $\alpha / \beta$ heterodimer and the CD3 complex of a human CD4+ T cell clone. This inhibition was observed in an APC-free cell system and was therefore clearly independent of APC-T cell interaction. Most previous studies on the effect of HIV on T cell responses dealt with the inhibitory action of $\mathrm{gp} 120$. However, HIV gp41, which results from the cleavage of gp 160 into gp 120 and gp41 moieties, has also been reported to alter $T$ cell function. A gp41-derived 17 mer, pHIVIS, was shown to inhibit lymphocyte proliferation to CD3 in vitro (33). Moreover, a synthetic peptide with sequence identity to gp41 was able to inhibit PKC and anti-CD3-induced $\mathrm{Ca}^{2+}$ influx in Jurkat $\mathrm{T}$ cells (34). However, our data show that both purified recombinant gp 120s and gp 160s similarly impair the response of P28D $T$ cell clone via the CD3/TcR molecule. These findings may 

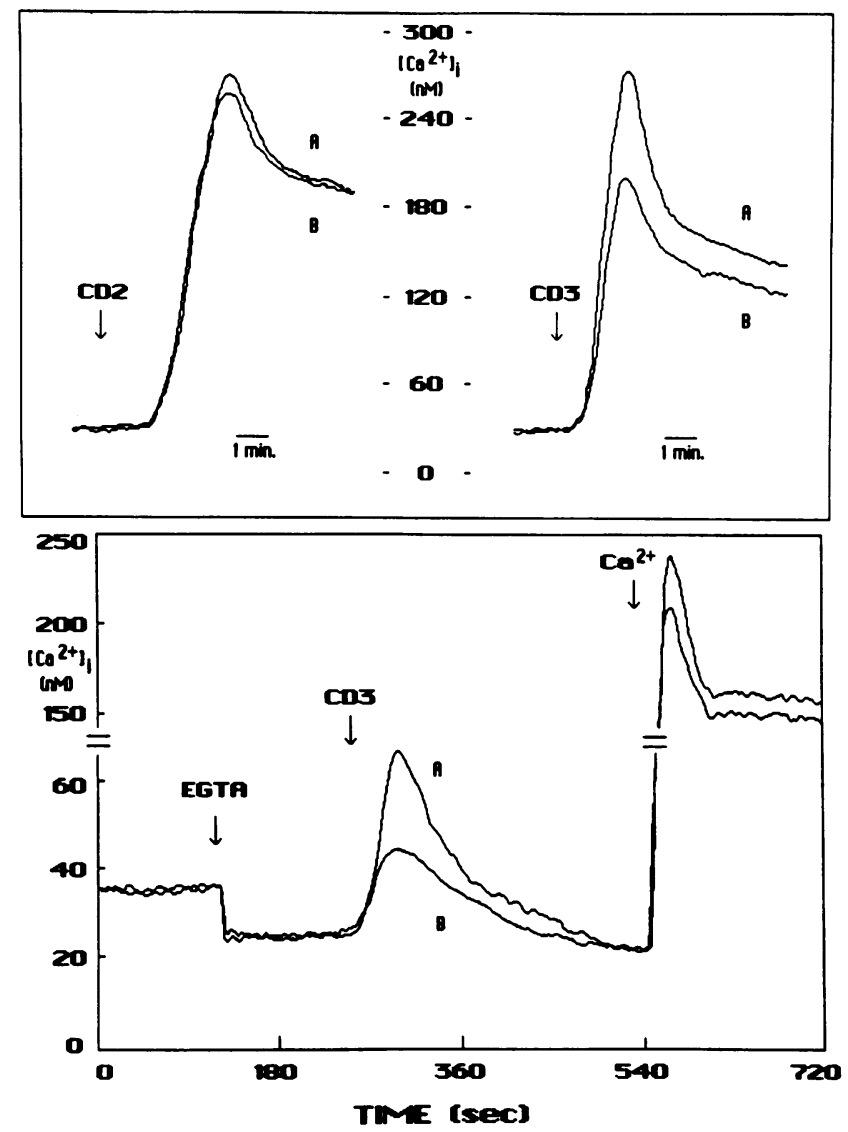

Figure 5. Effect of gp160s on the $\mathrm{Ca}^{2+}$ response to $\mathrm{CD} 2$ and CD3specific MAbs. (Top) CD3-specific MAb UCHT1 (1/400 dilution) or CD2-specific MAbs X11/D66 (1/400 dilution) were added on control $(A)$ or gp160s $(4 \mu \mathrm{g} / \mathrm{ml})$ overnight-treated $(B)$ P28D T cells, in the presence of $1 \mathrm{mM}$ extracellular $\mathrm{Ca}^{2+}$. (Bottom) Extracellular $\mathrm{Ca}^{2+}$ was depleted by the addition of $3 \mathrm{mM}$ EGTA before addition of MAb UCHT1 (1/400 dilution) on control $(A)$ or gp160s $(4 \mu \mathrm{g} / \mathrm{ml})$ overnight-treated $(B)$ P28D T cells. After the transient increase in $\left[\mathrm{Ca}^{2+}\right]_{\mathrm{i}}$, extracellular $\mathrm{Ca}^{2+}$ was restored by the addition of $5 \mathrm{mM}$ $\mathrm{CaCl}_{2}$. All measurements were made with Fura-2-loaded cells as described in Methods. Each tracing is representative of three different experiments.

indicate no additional inhibitory role for the gp 41 moiety in our $\mathrm{T}$ cell clone model. Whether internalization of gp41 resulting from the cleavage of gp160 may be critical for immunosuppressive function, as suggested by Ruegg et al. (34), can-

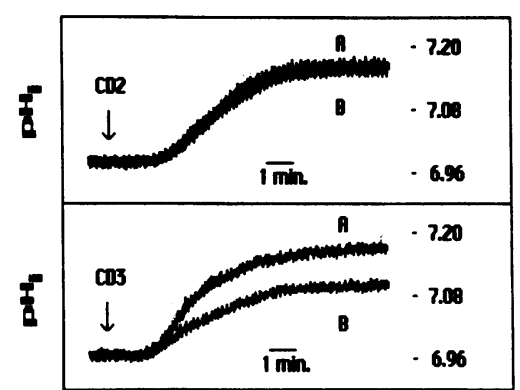

Figure 6. gp160s only affects the P28D T cell $\mathrm{pH}_{\mathrm{i}}$ response to $\mathrm{CD} 3$ stimulation. Control $(A)$ or overnight-gp $160 \mathrm{~s}$ pulsed (B) P28D T cells were loaded with BCECF/AM for $30 \mathrm{~min}$ and resuspended in PBS in a stirred cuvette at $37^{\circ} \mathrm{C}$. Cells were then stimulated with CD3specific MAb UCHT1

(1/400 dilution) or CD2-specific MAbs X11/D66 (1/400 dilution). Shown are representative tracings from three separate experiments. not be addressed by studies with the whole gp 160 molecule. So the effect of purified gp41 alone needs to be further investigated in our model.

Activation of T lymphocytes is initiated by hydrolysis of PI 4,5-biphosphate by PLC into two second messengers, inositol 1,4,5-triphosphate $\left(\mathrm{IP}_{3}\right)$ and $\mathrm{DAG}$. The former induces release of $\mathrm{Ca}^{2+}$ from intracellular stores $(27,28)$ while DAG activates PKC (35). Triggering of these early activation events may be achieved in P28D T cell clone by MAbs specific for the CD2 or CD3/TcR molecules $(22,23)$. Although CD2 and CD3 MAbs were both used in saturating concentrations for optimal responses, only CD3/TcR-stimulated PLC pathway was inhibited in clone P28D by gps. This apparent specificity of gps inhibition in phosphoinositide hydrolysis and turnover experiments could be related to greater responsiveness to $\mathrm{CD} 2$ triggering. However, only $\mathrm{CD} 3$-induced $\mathrm{Ca}^{2+}$ and $\mathrm{pH}_{\mathrm{i}}$ responses were inhibited by gps, although they were similarly increased by $\mathrm{CD} 2$ and $\mathrm{CD} 3$.

Kornfeld et al. (36) demonstrated that gp 120 partially purified from supernatants of HIV-infected T cells could induce rapid $\mathrm{IP}_{3}$ accumulation and $\mathrm{Ca}^{2+}$ response in resting $\mathrm{T}$ cells. In our study, gps failed to trigger either a proliferative response or early signal transduction events in P28D T cell clone. This discrepancy may be due to their use of a highly impure preparation of viral envelope instead of purified recombinant gp120. Kornfeld et al. also recently reported (personal communication) that a 24-h exposure of PBL and Jurkat cells to $10^{-8} \mathrm{M}$ gp120 resulted in a progressive decrease in the $\mathrm{Ca}^{2+}$ response. Our time-course experiments showed that inhibition by gps of the CD3/TcR-triggered IPs production was not observed for short incubations with gps $(<2 \mathrm{~h})$, but was maximal after a 16-h exposure to gps. Mechanisms of such a delayed impairment are as yet unknown. We showed in this study that gp120s' disappearance from the surface of clone P28D had a similar kinetics to IPs inhibition. However, we do not know whether the viral glycoprotein was internalized or shed from cells. Studies are currently underway to appreciate the role of gp120 internalization in our $T$ cell model.

Linette et al. (7) have shown that $\mathrm{T}$ cell responses to CD3specific MAbs and CD4 membrane expression were decreased in HIV-1-infected $T$ cells, suggesting that CD4 should participate in the CD3-induced T cell activation events. Loss of CD4 membrane expression and CD4 mRNA was also demonstrated on peripheral blood mononuclear cells during acute HIV replication (37). On the other hand, increasing evidence suggests that the CD4 molecule may not only act as an accessory molecule. Thus, perturbation of the CD4 molecule by specific MAbs may transmit a regulatory signal to the CD3/ TcR complex (13). Ledbetter et al. demonstrated that crosslinking of CD4 by specific MAbs could inhibit the CD3-mediated $\mathrm{Ca}^{2+}$ responses (12). Moreover, comodulation studies suggest that CD4 may be physically and perhaps functionally associated with the CD3/TcR complex on activated $T$ cells $(38,39)$. Since CD4 has been identified as the specific receptor for the HIV-1 envelope glycoprotein gp 120 (40), these findings may account for some of the reported inhibitory effects of the viral glycoprotein on the $T$ cell activation process mediated through the human CD3/TcR. In agreement with Weinhold et al. (9), we found that CD4 expression at the P28D cell surface was not decreased after a 2-h exposure to gp120s. However, membrane CD4 levels were reduced after a prolonged exposure to the viral glycoprotein. This was correlated with the 
time-course of gps-induced inhibitions on P28D T cell responses to CD3 stimulation. As CD4 was also shown to enhance $T$ cell responses to $C D 3$ when brought into close physical proximity to the CD3/TcR complex (12), modulation of CD4 by gps could partially account for the observed impairment in the CD3/TcR-triggered P28D T cell activation. Mittler et al. (41) reported a synergism between gp 120 and IgG fractions from HIV-infected individuals in blocking human T cell activation by formation of complexes that could modulate CD4 membrane levels. Addition of a gp120-specific MAb failed to increase sensitivity of P28D T cell responses to the inhibitory effects of gps (not shown).

Veillette et al. (42) and Rudd et al. (43) have recently reported in both the murine and the human systems that the CD4 receptor was associated with the protein-tyrosine kinase activity pp56 ${ }^{\text {lck. }}$. The former (44) also showed that cross-linking of the CD4 receptor with CD4-specific MAbs induced a rapid increase in this activity associated with the phosphorylation of the zeta subunit of the CD3 multimeric complex. Function of p56 ick is not known but it was suggested that it could be a component of the signal transduction system regulating $\mathrm{T}$ cell activation. However, gp120 failed to induce phosphorylation of CD4 (45). It is clear in our system that only long-term exposure of T cell clone P28D to gps induced anti-CD3 unresponsiveness. These observations therefore make the involvement of pp $56^{\text {lck }}$ in the observed effect of gps very elusive.

Studies of Lamarre et al. $(46,47)$ showed that gp120 and MHC class II molecules may interact with distinct but close regions on the CD4. Finally, it is conceivable from our results that gps binding to CD4 may interfere with the normal CD3/ TcR activation process by two distinct, but not mutually exclusive, mechanisms, involving inhibition of APC-T cell interaction and direct transmission of negative signals via the CD4 in the absence of APC. There is no clear evidence for detectable amounts of soluble gp 120 in blood of infected patients. However, we can expect from our in vitro results that low levels of gp120 that may be released from HIV-infected T cells (1) and adsorbed on the $T$ cell surface in the absence of virus production could partially explain the observed impairment of uninfected $T$ cells' function, especially at early stages of the disease. This may be of importance when considering HIV-1 envelope glycoproteins in vaccinal strategies.

\section{Acknowledgments}

We thank H. Gouy for her expert technical assistance. We would also like to acknowledge I. Diaz and M. Ollivier (Pasteur Vaccins) for production and purification of gp160s and gp120s, and H. Kolbe (Transgène) for fruitful discussions about purification.

This work was supported by grants from the Institut National pour la Santé et la Recherche Médicale and the Caisse Nationale d'Assurance Maladie. Dr. Cefai is a recipient of the Agence Nationale pour la Recherche contre le SIDA.

\section{References}

1. Fauci, A. S. 1988. The human immunodeficiency virus: infectivity and mechanisms of pathogenesis. Science (Wash. DC). 239:617623.

2. Chirmule, N., V. Kalyanaraman, N. Oyaizu, and S. Pahwa. 1988. Inhibitory influences of envelope glycoproteins of HIV-1 on normal immune responses. J. Acquired Immune Defic. Syndr. 1:425430.
3. Gurley, R. J., K. Ikeuchi, R. A. Byrn, K. Anderson, and J. E. Groopman. 1989. CD4+ lymphocyte function with early human immunodeficiency virus infection. Proc. Natl. Acad. Sci. USA. 86:19931997.

4. Diamond, D. C., B. P. Sleckman, T. Gregory, L. A. Lasky, J. L. Greenstein, and S. J. Burakoff. 1988. Inhibition of CD4+ T cell function by the HIV envelope protein gp 120. J. Immunol. 141:3715-3717.

5. Schwartz, R. H. 1982. Functional properties of the I region gene products and theory of the immune response (Ir) gene function. In Ia Antigens. S. Ferrone and C. S. David, editors. CRC Press, Inc., Boca Raton, FL. 161-178.

6. Gay, D., P. Maddon, R. Selaky, M. A. Talle, M. Godfrey, E. Long, G. Goldstein, L. Chess, R. Axel, J. Kappler, and P. Marrack. 1987. Functional interaction between human T-cell protein CD4 and the major histocompatibility complex HLA DR antigen. Nature (Lond.). 328:626-629.

7. Linette, G. P., R. J. Hartzman, J. A. Ledbetter, and C. H. June. 1988. HIV-1-infected T cells show a selective signaling defect after perturbation of CD3/antigen receptor. Science (Wash. DC). 241:573576.

8. Mann, D. L., F. Lasane, M. Popovic, L. O. Arthur, W. G. Robey, W. A. Blattner, M. J. Newttner, and M. J. Newman. 1987. HTLV-III large envelope protein (gp120) suppresses PHA-induced lymphocyte blastogenesis. J. Immunol. 138:2640-2644.

9. Weinhold, K. J., H. K. Lyerly, S. D. Stanley, A. A. Austin, T. J. Matthews, and D. P. Bolognesi. 1989. HIV-1 gp120-mediated immune suppression and lymphocyte destruction in the absence of viral infection. J. Immunol. 142:3091-3097.

10. Bekoff, M., T. Kakiuchi, and H. M. Grey. 1985. Accessory cell function in the Con A response: role of Ia positive and Ia negative accessory cells. J. Immunol. 134:1337-1342.

11. Wassmer, P., C. Chang, L. Lodgberg, and E. M. Shevach. 1985. Role of the L3T4-antigen in T cell activation. II. Inhibition of T cell activation by monoclonal anti-L3T4 antibodies in the absence of accessory cells. J. Immunol. 135:2237-2242.

12. Ledbetter, J. A., C. H. June, P. S. Rabinovitch, A. Grossmann, T. T. Tsu, and J. B. Imboden. 1988. Signal transduction through CD4 receptors: stimulatory vs inhibitory activity is regulated by CD4 proximity to the CD3/T cell receptor. Eur. J. Immunol. 18:525-532.

13. Bank, I., and L. Chess. 1985. Perturbation of the T4 molecule transmits a negative signal to T cells. J. Exp. Med. 162:1294-1303.

14. Wain-Hobson, S., P. Sonigo, O. Danos, S. Kole, and M. Alizon. 1985. Nucleotide sequence of the AIDS virus, LAV. Cell. 40:9-17.

15. Kieny, M. P., R. Lathe, Y. Riviere, K. Dott, D. Schmitt, M. Girard, L. Montagnier, and J. P. Lecocq. 1988. Improved antigenicity of the HIV env protein by cleavage site removal. Protein Eng. 2:219225.

16. Deen, K. C., J. S. Mc Dougal, R. Inacker, G. Folena-Wasserman, J. Arthos, J. Rosenberg, P. J. Maddon, R. Axel, and R. W. Sweet. 1988. A soluble form of CD4 (T4) protein inhibits AIDS virus infection. Nature (Lond.). 331:82-84.

17. Kurrle, R., W. Seyfert, A. Trautwein, and F. R. Seiler. In Leucocyte Typing II. E. L. Reinherz et al., editors. Springer Verlag, Berlin and New York. 137-146.

18. Huet, S., H. Wakasugi, G. Sterkers, J. Gilmour, T. Tursz, L. Boumsell, and A. Bernard. 1986. T cell activation via CD2 [T, gp50]: the role of accessory cells in activating resting $\mathrm{T}$ cells via $\mathrm{CD} 2 . J$. Immunol. 137:1420-1428.

18a. Bismuth, G., H. Gouy, R. A. Mariuzza, C. Vaquero, I. Theodorou, and P. Debré. 1990. A human TCR-Ig chimeric protein used to generate a TCR chain variable region-specific mAb. Mol. Immunol. In press.

19. Triebel, F., V. Missenard-Leblond, B. Autran, M. C. Couty, D. J. Charron, and P. Debré. 1984. Antigen-specific proliferative human $\mathrm{T}$ cell clones with specificity for diphteria toxoid: genetic and molecular restriction by class II antigens. Eur. J. Immunol. 14:697702.

20. Klohe, E. P., R. Watts, M. Bahl, C. Alber, W. Yu, R. Anderson, 
J. Silver, P. K. Gregersen, and R. W. Karr. 1988. Analysis of the molecular specificities of anti-class II monoclonal antibodies by using L cell transfectants expressing HLA class II molecules. J. Immunol. 141:2158-2164.

21. Bismuth, G., H. Gouy, R. W. Karr, and P. Debre. 1990. Identification of cross-reactive $T$ cell restriction epitopes located on the DR7 $\beta 1$ and DR $\beta 4$ molecules. Human Immunol. 28:271-280.

22. Bismuth, G., I. Theodorou, H. Gouy, S. Le Gouvello, A. Bernard, and P. Debré. 1988. Cyclic AMP-mediated alteration of the CD2 activation process in human T lymphocytes. Preferential inhibition of the phosphoinositide cycle-related transduction pathway. Eur. J. Immunol. 18:1351-1357.

23. Bismuth, G., F. Faure, I. Theodorou, P. Debré, and T. Hercend. 1988. Triggering of the phosphoinositide transduction pathway by a monoclonal antibody specific for the human $\gamma / \delta \mathrm{T}$ cell receptor. Eur. J. Immunol. 18:1135-1138.

24. Grynkiewicz, G., M. Poenie, and R. Y. Tsien. 1985. A new generation of $\mathrm{Ca} 2+$ indicators with greatly improved fluorescence properties. J. Biol. Chem. 260:3440-3448.

25. Grinstein, S., S. Cohen, and A. Rothstein. 1984. Cytoplasmic pH regulation in thymic lymphocytes by an amiloride-sensitive $\mathrm{Na}^{+} / \mathrm{H}^{+}$antiport. J. Gen. Physiol. 83:341-369.

26. Hofman, B., K. D. Jakobsen, N. Odum, E. Dickmeiss, P. Platz, L. P. Ryder, C. Pedersen, L. Mathiesen, I. Bygbjerg, V. Faber, and A. Svejgaard. 1989. HIV-induced immunodeficiency. Relatively preserved phytohemagglutinin as opposed to decreased pokeweed mitogen responses may be due to possibly preserved responses via CD2/ phytohemagglutinin pathway. J. Immunol. 142:1874-1880.

27. Imboden, J. B., C. Weyand, and J. Goronzy. 1987. Antigen recognition by a human $T$ cell clone leads to increases in inositol triphosphate. J. Immunol. 138:1322-1324.

28. Imboden, J. B., and J. D. Stobo. 1985. Transmembrane signalling by the $T$ cell antigen receptor. Perturbation of the T3-antigen receptor complex generates inositol phosphates and releases calcium ions from intracellular stores. J. Exp. Med. 161:446-456.

29. Pantaleo, G., D. Olive, A. Poggi, W. J. Kozumbo, L. Moretta, and A. Moretta. 1987. Transmembrane signalling via the T11-dependent pathway of human $T$ cell activation. Evidence for the involvement of 1,2-diacylglycerol and inositol phosphates. Eur. J. Immunol. 17:55-60.

30. Matthews, T. J., K. J. Weinhold, H. K. Lyerly, A. J. Langlois, H. Wigzell, and D. P. Bolognesi. 1987. Interaction between the human $T$ cell lymphotropic virus type $\mathrm{III}_{B}$ envelope glycoprotein gp1 20 and the cell surface antigen CD4: role of carbohydrate in binding and cell fusion. Proc. Natl. Acad. Sci. USA. 84:5424-5429.

31. Gardner, P., A. Alcover, M. Kuno, P. Moingeon, C. M. Weyand, J. Goronzy, and E. L. Reinherz. 1989. Triggering of T-lymphocytes via either T3-Ti or T11 surface structures opens a voltage-insensitive plasma membrane calcium-permeable channel: requirement for interleukin-2 gene function. J. Biol. Chem. 264:1068-1076.

32. Gelfand, E. W., G. B. Mills, R. K. Cheung, J. W. W. Lee, and S. Grinstein. 1987. Transmembrane ion fluxes during activation of human $\mathrm{T}$ lymphocytes: role of $\mathrm{Ca}^{2+}, \mathrm{Na}^{+} / \mathrm{H}^{+}$exchange and phospholipid turnover. Immunol. Rev. 95:59-64.

33. Cianciolo, G. J., H. Bogerd, and R. Snyderman. 1988. Human retrovirus-related synthetic peptides inhibit $\mathrm{T}$ lymphocyte proliferation. Immunol. Lett. 19:7-14.

34. Ruegg, C. L., and M. Strand. 1990. Inhibition of protein kinase $\mathrm{C}$ and anti-CD3-induced $\mathrm{Ca}^{2+}$ influx in Jurkat $\mathrm{T}$ cells by a synthetic peptide with sequence identity to HIV-1 gp41. J. Immunol. 144:3928-3935.

35. Nishizuka, Y. 1984. The role of protein kinase $C$ in cell surface transduction and tumor promotion. Nature (Lond.). 308:693-696.

36. Kornfeld, H., W. W. Cruikshank, S. W. Pyle, J. S. Berman, and D. M. Center. 1988. Lymphocyte activation by HIV-1 envelope glycoprotein. Nature (Lond.). 335:445-448.

37. Salmon, P., R. Olivier, Y. Riviere, E. Brisson, J.-C. Gluckman, M.-P. Kieny, L. Montagnier, and D. Klatzmann. 1988. Loss of CD4 membrane expression and CD4 mRNA during acute human immunodeficiency virus replication. J. Exp. Med. 168:1953-1969.

38. Rivas, A., S. Takada, J. Koide, G. Sonderstrup-Mc Devitt, and E. G. Engleman. 1988. CD4 molecules are associated with the antigen receptor complex on activated but not resting T cells. J. Immunol. 140:2912-2918.

39. Saizawa, K., J. Rojo, and C. A. Janeway, Jr. 1987. Evidence for a physical association of CD4 and the CD3: $\alpha: \beta$ T cell receptor. Nature (Lond.). 328:260-263.

40. Klatzmann, D., E. Champagne, S. Chamaret, J. Gruest, D. Guetard, T. Hercend, J. C. Gluckman, and L. Montagnier. 1984. Tlymphocyte T4 behaves as the receptor for human retrovirus LAV. Nature (Lond.). 312:767-771.

41. Mittler, R. S., and M. K. Hoffman. 1989. Synergism between HIV gp120 and gp120-specific antibody in blocking human T cell activation. Science (Wash. DC). 245:1380-1382.

42. Veillette, A., M. A. Bookman, E. M. Horak, and J. B. Bolen. 1988. The CD4 and CD8 T cell surface antigens are associated with the internal membrane tyrosine-protein kinase p56 $6^{\text {lck }}$. Cell. 55:301-308.

43. Rudd, C. E., J. M. Trevillyan, J. D. Dasgupta, N. L. Wong, and S. F. Schlossman. 1988. The CD4 receptor is complexed in detergent lysates to a protein-tyrosine kinase (pp58) from human T lymphocytes. Proc. Natl. Acad. Sci. USA. 85:5190-5194.

44. Veillette, A., M. A. Bookman, E. M. Horak, L. E. Samelson, and J. B. Bolen. 1989. Signal transduction through the CD4 receptor involves the activation of the internal membrane tyrosine-protein kinase p56 ${ }^{\text {lck. }}$. Nature (Lond.). 338:257-259.

45. Fields, A. P., D. P. Bednarik, A. Hess, and W. S. May. 1988. Human immunodeficiency virus induces phosphorylation of its cell surface receptor. Nature (Lond.). 333:278-280.

46. Lamarre, D., J. C. Capon, D. R. Karp, T. Gregory, E. O. Long, and R. P. Sekaly. 1989. Class II MHC molecules and the HIV gp120 envelope protein interact with functionally distinct regions of the CD4 molecule. EMBO (Eur. Mol. Biol. Organ.) J. 8:3271-3277.

47. Lamarre, D., A. Ashkenazi, S. Fleury, D. H. Smith, R. P. Sekaly, and D. J. Capon. 1989. The MHC-binding and gp 120-binding functions of CD4 are separable. Science (Wash. DC). 245:743-746. 